\title{
When solidarity and misery meet in the shadow of a massacre: Moral values reflected in the novel 'Human Acts'
}

\author{
${ }^{1}$ Audi Yundayani*, ${ }^{2 B e n e d i c t a ~ L i n t a n g ~ L a r a s s a t y, ~}{ }^{2 B e j o}$ Sutrisno \\ ${ }^{1}$ STKIP Kusuma Negara, Indonesia \\ ${ }_{2}^{2}$ Sekolah Tinggi Bahasa Asing (STIBA) IEC, Jakarta, Indonesia
}

*Corresponding Author

audi_yundayani@stkipkusumanegara.ac.id

Received:

14 October 2020
Revised:

7 January 2021
Accepted:

27 February 2021
Published:

28 February 2021

\begin{abstract}
The crisis that the world is in today has brought people together through the suffering they share. It leads to the presence of solidarity, which shows how people come hand in hand to help each other, showing that humanity exists even in difficult times. This paper seeks to analyze the portrayal of solidarity and suffering as part of the moral values of Han Kang's novel 'Human Acts,' which deals with the similar crisis that occurred in South Korea in 1980, known as the Gwangju Uprising. It applies descriptive qualitative research which concentrates directly and clearly on the aspects of moral values in the novel. It is learned that the characters in the novel convey the moral values most through the way in which they respect and care for one another, and that the suffering shared between the characters is part of both their loss and their survival because of the solidarity they have built along the way. The moral values depicted in the novel 'Human Acts' are not merely fiction. It was realistically shown during the Gwangju Uprising and is now being shown in the current situation of the pandemic.
\end{abstract}

Keywords: Moral values; novel 'Human Acts'

\section{INTRODUCTION}

Since the beginning of 2020, the world has been faced with an unexpected pandemic, with lives being drastically altered and even stolen. There are, however, stories worth telling and messages worth sharing. The story of people who actively risk their lives by standing in the front line to combat this pandemic is just one of those messages that is worth sharing in every form of media, like a novel. Even if the novel deals with an unrelenting portrait of death and agony, it is still the author's freedom as the way he decides to convey the message that needs to be shared with readers in order to build up the optimistic attitude of the reader. Marsh (2002) assumed that literature is concerning with life and leaving. This is due to the fact that literary texts convey both writers' and readers' philosophies and beliefs as a type of social construction (Zyngier, 1994; Ariyanti, 2016) and that literary texts such as novels can be analysed in a number of ways that will lead to the same aim, that is, to make readers grasp what the authors plan to communicate.

There are two aspects that have an impact on the content of a novel. They are the extrinsic and intrinsic structures of the novel itself. The extrinsic 
Yundayani, A., Larassaty, B. L., \& Sutrisno, B. (2021). When solidarity and misery meet in the shadow of a massacre: Moral values reflected in the novel 'Human Acts'. EduLite: Journal of English Education, Literature, and Culture, 6 (1), 105-119. http://dx.doi.org/10.30659/e.6.1.105-119

structures relate to the social context of the novel (Wellek \& Warren, 2012). They are seen from history to the present day, telling the events that are going on in the novel. They also weigh beyond novels, but they have an indirect influence on the construction and system of a novel. Thus, the extrinsic elements of a novel must always be seen as significant. Intrinsic structures weigh on all aspects of the novel itself. Klarer (2016) suggested four inner frameworks of novels, which are: (1) plot; (2) character; (3) point of view; (4) set-up; (5) theme.

In general, the definition of morality has been established from the point of view of society that it is reasonable to call it the highest good. We may conclude that it is important to decide what is right and what is wrong if it is based on the values of the standard. In this case, it is claimed that morality is a term which refers to attitudes of reverence, obligation, integrity and honesty (Kaur, 2015). Morality is made up of two primary components for a more precise interpretation of the terms of respect. They are how to value oneself and value others in terms of values, views and community. In addition, Lickona (1996) argued that accountability requires consideration of the lives and rights of other people in the socio-economic, political and cultural activities of society.

Moral values do not only affect people 's obligation to recognize the lives of others or to behave according to one's conscience, but they also affect two aspects that ultimately contribute to the concept of moral values, which are suffering and solidarity. Suffering is related to moral beliefs, and is used to mean the subjective experience of those who are disadvantaged or victims of oppression. When used in this manner, the term, by its very nature, implies a moral judgment on the actions of another. To claim that some people are oppressed is to say that some people are oppressing them or behaving unfairly against them and that, as a result, these people should change their actions in order to bring an end to the discrimination and eliminate the injustice. To quote someone's misery is a moral condemnation (Mayerfeld, 1999) as well.

If one encounters suffering and it is shared among others, empathy will rise to the surface to help them endure their suffering. Seen from its descriptive senses, solidarity is a kind of connection to others, to other members of a group, large or small. It can be used to define and justify normal order and normative social inclusion in cultures or populations, as opposed to disorder and conflict, and as opposed to order based on manipulation or maximization of self-interest (Laitinen \& Pessi, 2005).

Seeing how misery and solidarity relate to each other and how moral values are described, Kinnier et al (2000) suggested four dimensions of moral values, taken from the term universal values, which came from a variety of experts with their theories and arguments. One argument is that universal principles are about a modesty theory that tells people how to act in life, like how to honor others or how to value others' human rights (Kinnier et al., 2000). The dimensions of moral values are: (1) commitment to something greater than oneself; (2) self-esteem, but with modesty or esteem for others; self-discipline and acknowledgement of personal responsibility; (3) respect and care for others; (4) concern for all living beings and the world. These dimensions have their own measures, which are used as an instrument for this analysis.

The world's current situation, in some ways, is close to that faced by South Korea in Gwangju in 1980. It was when General Chun Doo-hwan stepped into the throne with strong ideas about how citizens should be governed that a 
demonstration led by students took place in Gwangju. Students and citizens in Gwangju called for the rebuilding of national democracy by halting martial law, restoring freedom of the press, and re-opening universities, but it turned out to be a brutal massacre by paratroopers and high-ranking soldiers. However, in those dark days, there were people who risked their lives helping victims and families, and there were stories that often represented the unity people see today. If a line is drawn to see a message that tells how these incidents of various times are related to one another, then there must be a mutual solidarity between people in these difficult times of distress. Rakopoulos (2016) argued that solidarity is an idea that inspires people in a crisis of everyday life. The misery that people have endured during the crisis is one of the real appeals to be more compassionate and to create unity in the hope of saving and surviving each other.

This message about becoming human by unity is portrayed in one of the works by Han Kang, a South Korean author who won the Man Booker International Prize in 2016, in her second translated novel, Human Acts. Through Human Acts, readers are given an image of how the suffering that occurred to the people as a result of violence during the Gwangju Uprising gradually united them to survive, even if it left some marks that could not just fade away. Since the novel depicts many issues related to moral values through the actions and experiences of the characters in the novel, the message that Kang wants to convey becomes clearer as the author of this analysis seeks to find out how solidarity and suffering become the strength of the novel. It's about how, even during the time of hardship, Kang succeeds in giving the gallant picture of her characters in the front line to help victims and wounded people without thinking about losing their lives, which has struck a chord with the researchers. This is the phenomenon that is currently taking place during this pandemic, to which most people can relate. Thus, this study is carried out as a wish of the writer to share Kang's message through the moral values portrayed in the Human Acts, which are seen through the inner frameworks of the novel and the dimension of moral values. Taking the issue above as the point of departure, the aims of the study are formulated into the following research questions,

1. What are the moral values taken from the intrinsic structures of the novel Human Acts?

2. What are the moral values that the novel Human Acts depicts?

\section{METHOD}

This research applied qualitative research design, which is a form of social science research that begins by looking for patterns or relationships while collecting data to interpret meaning from data that allow the researcher to understand social life through the study of a particular topic (Djamba \& Neuman, 2002).

The object of this study is the novel of Human Acts. It is a Han Kang's novel of the 1980 Gwangju uprising and its aftermath, people are spilling blood, and people are courageous enough to donate it. With such a sharp awareness that it is excruciating, the Human Acts attempt to resolve these paradoxical and coexisting humanities. Han Kang is a South Korean author who received The Man Booker International Prize award in 2016 for her previous novel, The 
Yundayani, A., Larassaty, B. L., \& Sutrisno, B. (2021). When solidarity and misery meet in the shadow of a massacre: Moral values reflected in the novel 'Human Acts'. EduLite: Journal of English Education, Literature, and Culture, 6 (1), 105-119. http://dx.doi.org/10.30659/e.6.1.105-119

Vegetarian. This second translated novel of hers, Human Acts, is as a source of data which the data taken from words.

The Human Acts novel by Han Kang provided readers with the opportunity to gain an insight into survivors and victims of the Gwangju uprising, South Korea and its consequences. Hartanto (2018) discussed how the survivors memorize and blend in to politically and culturally forget the shooting and the State attempts to do so. Through his studies, Hartanto explored the mechanism of the Gwangju survivors' recuperation and forgetting and gathering knowledge in close reading using the theoretic of social remembrance by Barbara Misztal. The result showed that organizations, such as the family, museums, mass media and the state, constantly recall and forget the process. Harahap \& Utami (2019) also analyzed the novel by employing the representational theory by Stuart Hall. According to the major historical accounts, Human Acts novel reflects what happened in the rebellion and how civilians with power could cause trouble. The life story of groups of movement organizations was identified by Kahn-chae (2003). The Gwangju uprising's growth, which took 10 days in May 1980, defined the early phase of the uprising based on collective behaviour theory. Groups of movement organizations subsequently emerged with complex connections. Last but not least, relationships reduced to two modes of solidarity: settlement vs struggle. Struggle solidarity eventually forced out the solidarity of settlements and seized the uprising's hegemony. The varying views in the study of the contents of Human Acts novel affected readers' wider views as they saw the author's messages. The values of this new Human Act also could be connected to and mirrored by the readers.

\section{Instruments}

The main instrument used in this study is the researchers themselves, as this study is part of the qualitative research methodology. The researchers analysed the material of the novel Human Acts based on the perspectives of universal moral principles by Kinnier et al. (2000). They listed four main categories: (1) commitment to something greater than oneself; (2) self-esteem, but with humility, self-discipline and acceptance of personal responsibility; (3) respect and caring for others; (4) caring for other living things and the environment. Analysing the data with a view to obtaining the results, researchers are exploring more of these main categories into more precise values as indicators.

\section{Procedures}

This study applied qualitative research, which aims to focus on the mechanism that is occurring in the process of this research. Fraenkel \& Wallen (1993) argued that the data should be consistently observed in order to provide a meaningful and reliable outcome. It is clear that the part of data collection in research is very urgent and critical.

The data collection procedure has been systematically outlined as follows: (1) the researcher prepares the novel Human Acts and has a mature understanding of the moral values as a key component of this research; (2) the researcher reads the novel's content carefully while writing important notes and codes; (3) the identification of appropriate data, which only focuses on the research; (4) the researcher shall re-check the data collected in order to have the data valid as the last step of this procedure. 


\section{Data analysis}

This study applied qualitative analysis, which can be seen as interpretative, in which researchers make a personal evaluation of a description that matches the situation or themes of the major categories of data. Researchers relate research findings to research goals and objectives using noteworthy transcript quotations to highlight key themes inside outcomes and possible discrepancies.

This research has continued through steps that are not always taken in sequence, but which reflect the preparation and arrangement of data for analysis. The interrelated steps involved in qualitative data analysis and interpretation include: (1) preparing and organizing data taken from the novel Human Acts for analysis; (2) exploring and coding data; (3) coding for the compilation of descriptions and themes; (4) presenting and reporting qualitative findings; (5) interpreting findings; (6) validating the accuracy of findings through triangulation (Creswell, 2012).

\section{RESULTS AND DISCUSSION \\ Moral values derived from the intrinsic structures of the novel Human Acts}

Researchers studied the moral values of the novel Human Acts from the intrinsic structures. The results identified the moral values found by reference taken from the plot, character, point of view, setting, and theme. Moreover, these results are summarized in a table to make it easier to learn about the categorization of the moral values seen from the novel's intrinsic structures. Table 1 shows the number of moral values derived from the intrinsic structures.

Table 1. Number of moral values derived from the intrinsic structures

\begin{tabular}{lccccc}
\multicolumn{1}{c}{ Dimensions of moral values } & Plot & Character & $\begin{array}{c}\text { Point } \\
\text { of view }\end{array}$ & Setting & Theme \\
\hline $\begin{array}{l}\text { Commitment to something greater to } \\
\text { oneself }\end{array}$ & 2 & 5 & 4 & 1 & NA \\
\hline $\begin{array}{l}\text { Self-respect, but with humbleness or } \\
\text { respect to others, self-discipline, and } \\
\text { acceptance of personal responsibility }\end{array}$ & 3 & 4 & 3 & 1 & 1 \\
\hline Respect and care for others & 6 & 5 & 7 & 1 & 1 \\
\hline $\begin{array}{l}\text { Caring for other living things and } \\
\text { environment }\end{array}$ & 2 & 2 & 1 & NA & NA \\
\hline
\end{tabular}

Table 1 identified that the major findings of this study are the intrinsic structure of the characters and the point of view. With 16 character findings and 15 findings from the point of view, the moral values contained in the Human Acts mainly come from people who witnessed unity and misery during the Gwangju Uprising. Other intrinsic structures that endorse the discovery of moral values in the Human Acts are the plot, with thirteen findings, the setting, and the theme, with three and two findings. All the results recorded in the table 1 will be further discussed, along with examples of narrative quotes and statements that illustrate moral values in the Human Acts. 
Yundayani, A., Larassaty, B. L., \& Sutrisno, B. (2021). When solidarity and misery meet in the shadow of a massacre: Moral values reflected in the novel 'Human Acts'. EduLite: Journal of English Education, Literature, and Culture, 6 (1), 105-119. http://dx.doi.org/10.30659/e.6.1.105-119

\section{Plot}

Moral values are seen in the plot by solidarity and misery as the story moves in stages. One of them comes from the tale of Jeong-dae, a Human Acts character who died during the rebellion and whose story is told by the spirit of Jeong-dae himself. There is a narration from Jong-dae that demonstrates how the story moves forward in his chapter that it finally led him to understand that he shared the same pain with other spirits he met.

"When a shadow that had been there from the first, and one that was newly arrived, both came to touch my own, extending along flat planes and folding over edges, I was somehow able to distinguish between them, though I couldn't have said how." (The Boy's Friend, 1980 P. 62 L. 7-10)

It is believed that Jeong-dae was puzzled about his life, apart from the fact that he died and his body was piled up with other victims' bodies, he did not know how to cope with the situation when he sensed the presence of other spirits around him. Then, as one of the complex mechanisms of the book, the story moves forward from a complication to a turning point for Jeong-dae (Klarer, 2016). He felt connected with other spirits as they touched his own, and he was able to identify them even though he wasn't sure how it happened. The fact that these people, including Jeong-dae, had endured the same pain that caused the most horrific harm in their lives before they died indicates the existence of mutual misery. As it is implied that often suffering simply refers to the experience of such objective calamities (Mayerfeld, 1999), the suffering they shared when they were alive is the reason why Jeong-dae was able to communicate with them, also in the form of spirits, by the feeling he had when other spirits touched him.

\section{Characters}

The existence of moral values is seen not only from the plot, but also from the characters in the Human Acts. One of them comes from a character who is called an inmate. The moral value derived from this character is part of the 'commitment to something greater than oneself' component, which points to the acknowledgement of the purpose of one's life in every way possible, including by pursuing justice for something that causes harm. Here the prisoner, who shared the same cell with Kim Jin-su, one of the students' leaders during the Gwangju Uprising, wondered about his life after the uprising.

"Given that I was partnered with Kim Ji-su and ate the exact same meals as him every single day, how come he died and I'm still living?" (The Prisoner, 1990 P. 108 L. 23-25)

It is believed that the prisoner wanted to know how to keep him alive when his cell mate, Kim Jin-su, died. The prisoner is conscious that they suffered in the same way during the rebellion, but Kim Jin-su decided to commit suicide ten years after the rebellion. The prisoner's thoughts on this matter are evidence that he felt the injustice of his fate and Kim Jin-su's, and tried to figure out why it happened as a gesture of reconciliation expressed between him and Kim Jinsu. 


\section{Point of view}

Moreover, moral values are often seen from the point of view of the characters as they experience incidents that demonstrate unity between people during the Gwangju Rebellion from their own viewpoints. One of them is expressed in the perspective of Kim Eun-sook, one of the girls who volunteered to support the victims and wounded in the provincial office during the uprising. Eun-sook observed one of the female student demonstrators declined to go home when she was asked to do so.

"We want to stay, too. We want to see this through together. That's why we came here, to be together." (The Editor, 1985 P. 89 L. 15-16)

The statement of the female student suggests that she knew the purpose of her life, which was to support the victims and the injured, and also to raise a voice to put an end to the violence perpetrated by the soldiers. This case depicted in the novel is similar to the actual one when more students came to the demonstration after hearing a story of a violent incident that occurred during the Gwangju Uprising (Kahn-Chae, 2003). In the book, from the viewpoint of Eun-sook, she saw a female student committed to herself that her life meant more than just going back home, remaining healthy when everyone was in great danger. This decision was made for a strong explanation that these students, even though they might suffer more, nevertheless feel unity within themselves during those tough times as a kind of moral obligation for the pain they shared with each other (Alexander, 2016).

\section{Setting (of time)}

Moral values seen in the Human Acts are not only seen during the Gwangju Uprising era. The life that characters have after the upheaval also portrays moral ideals that transcend time as a setting in the inner frameworks of the novel. One of them comes from a character named Lim Seon-ju who, even twenty-two years after the rebellion, still feels responsible for the death of Dongho, a 15-year-old boy who was one of the volunteers at the provincial office. Seon-ju tries to blame herself, speaking of Dong-ho.

"If I'd demanded that you go home, Dong-ho; if I'd begged, while we sat there eating gimbap, you would have done as I asked, wouldn't you? And that's why you're coming to me now. To ask why I'm still alive." (The Factory Girl, 2002 P. 173 L. 16-19)

It is believed that Lim Seon-ju still feels bad because she did not ask Dongho to go home when there was still a chance. That's why she feels the presence of him everywhere she goes, even though twenty-two years have passed. The manner in which she seeks to take blame for her inability to save Dong-ho at that time is part of the universal principles suggested by Kinnier et al. (2000).

\section{Theme}

Since the story in the Human Acts takes place within the framework of a realistic historical event, the Gwangju Rebellion, the novel is considered a historical 
Yundayani, A., Larassaty, B. L., \& Sutrisno, B. (2021). When solidarity and misery meet in the shadow of a massacre: Moral values reflected in the novel 'Human Acts'. EduLite: Journal of English Education, Literature, and Culture, 6 (1), 105-119. http://dx.doi.org/10.30659/e.6.1.105-119

novel. The unity and misery shown in the novel is one of the messages that the protagonist, Han Kang, wants to express through the memories of the uprising she shared, even though she was not in Gwangju when it happened. With the permission of Dong-ho 's brother in real life, Kang was able to write Human Acts while sticking to his words.

"Permission? Yes, you have my permission, but only if you do it properly.

Please, write your book so that no one will ever be able to desecrate my brother's memory again." (The Writer, 2013 P. 208 L. 9-11)

It indicates that Kang wrote Human Acts based on Dong-ho 's true story and that she wanted to bring the theme of moral values expressed in unity and misery by being true to the true memories of the people of Gwangju who were part of the Gwangju Uprising, particularly Dong-ho.

The findings of the moral values referred to in Table 1 are based on Kinnier et al. (2000) theory on the subject, which suggested four dimensions along with its own indicators, and the author found the results of those indicators in the novel Human Acts.

\section{Moral values portrayed in the novel Human Acts}

In order to boost the dispersion of dimensions in Kinner et al. (2000) moral values, the author addressed the findings set out in Table 2 . These results have been taken from the content of the novel itself.

Table 2. Number of moral values portrayed in the novel Human Acts

\begin{tabular}{|c|c|c|}
\hline \multicolumn{2}{|r|}{ Moral values } & \multirow{2}{*}{ Findings } \\
\hline Dimensions & Indicators & \\
\hline \multirow{3}{*}{$\begin{array}{l}\text { Commitment to something } \\
\text { greater to oneself }\end{array}$} & $\begin{array}{l}\text { To recognize the meaning and purpose of one's } \\
\text { existence }\end{array}$ & 5 \\
\hline & To seek truth & 3 \\
\hline & To seek justice & 4 \\
\hline \multirow{4}{*}{$\begin{array}{l}\text { Self-respect, but with } \\
\text { humbleness or respect to } \\
\text { others, self-discipline, and } \\
\text { acceptance of personal } \\
\text { responsibility }\end{array}$} & To respect and care for oneself & 2 \\
\hline & $\begin{array}{l}\text { To not exalt oneself, avoid greediness, and self- } \\
\text { centeredness }\end{array}$ & 2 \\
\hline & To act with conscience & 4 \\
\hline & To accept responsibility of one's behaviour & 4 \\
\hline \multirow{4}{*}{ Respect and care for others } & To recognize the connectedness of all people & 5 \\
\hline & $\begin{array}{l}\text { To serve and to be helpful to humankind and } \\
\text { individual }\end{array}$ & 6 \\
\hline & $\begin{array}{l}\text { To be caring, respectful, compassionate, tolerant, } \\
\text { and forgiving of others }\end{array}$ & 4 \\
\hline & $\begin{array}{l}\text { To not hurt others (e.g.: do not murder, abuse, steal } \\
\text { from, cheat, or lie to others) }\end{array}$ & 4 \\
\hline \multirow{2}{*}{$\begin{array}{l}\text { Caring for other living } \\
\text { things and environment }\end{array}$} & To consider one's own connection to nature & 2 \\
\hline & $\begin{array}{l}\text { To foster greater awareness of one's natural } \\
\text { surroundings }\end{array}$ & 3 \\
\hline
\end{tabular}

\section{Commitment to something greater to oneself}

The first component of moral values is 'commitment to something greater to oneself,' which refers to how people understand that their life means something and that they need to seek the reasons behind it. There are twelve studies that represent the moral values inherent in Human Acts through the dimension of 
'commitment to something greater than oneself.' The indicator of the recognition of the meaning and purpose of one's existence has more findings than the other two indicators.

This dimension is reflected through one of the narration from a character named Lim Seon-ju,

"But at the same time you know that if a time like that spring were to come round again, and even knowing what you know now, you might well end up making a similar choice to the one you'd made then." (The Factory Girl, 2002 P. 172 L. 22-25)

It is visible to see that Seon-ju has committed to herself that, even if those dark times during the rebellion are meant to happen again, Seon-ju will make the same decision to fight for justice and to put an end to violence despite the danger that could come upon her because, as a character, Seon-ju knows the sense and intent of her life.

Apart from understanding the sense and intent of one's life, the quest for truth and justice is often part of a dedication to something greater for oneself. If this occurs, there must be a breach of human nature and conscience, such as abuse. Violence that caused people in Gwangju to suffer intrinsically worse than unconsciousness (Mayerfeld, 1999) back in May, 1980, made them wonder what the nation is and why the soldiers even harmed the people they were supposed to defend. This is a thought shared by Dong-ho,

"Why would you sing the national anthem for the people who'd been killed by soldiers? Why cover the coffin with the Taegukgi? As though it wasn't the nation itself that had murdered them." (The Boy, 1980 P. 17 L. 11-14)

Having so many casualties and injured people in front of him, Dong-ho felt that the country had deceived its people by issuing orders to the soldiers to hurt them in order to strengthen martial law. This condition, however, did not split the people of Gwangju that quickly. In reality, greater solidarity is shared among them that a lot of volunteers, including Dong-ho, have come to help. This image is close to the real life scenario that someone said in an interview that people in Gwangju were beginning to share what they had. They came to help in their own way, as store owners opened their stores to customers free of charge (Choi, 2013).

\section{Self-respect, but with humbleness or respect to others, self dicipline, and acceptance of personal responsibility}

The second component of moral values is 'self-respect, but with humbleness or respect for others, self-discipline and acceptance of personal responsibility,' which refers to how people treat themselves after they have discovered the meaning behind their life. Twelve results for this dimension have also been found by the researcher. Indicators of behaving with conscience and taking responsibility for one's actions come with more results than others.

This dimension points to the fact that moral values come from themselves and that the way someone treats and acts towards one another would be their way of treating others. There are incidents, narrations, and utterances in the Human Acts that represent this dimension, one of which is when Dong-ho was 
Yundayani, A., Larassaty, B. L., \& Sutrisno, B. (2021). When solidarity and misery meet in the shadow of a massacre: Moral values reflected in the novel 'Human Acts'. EduLite: Journal of English Education, Literature, and Culture, 6 (1), 105-119. http://dx.doi.org/10.30659/e.6.1.105-119

too tired to keep on helping, so he did not force himself to remain awake. Instead, he wanted to take a nap for a while, thinking that he could make better use of it once he had recovered. This Dong-ho's behavior means that he cares not only for others, but also for himself. That way, he demonstrates that caring for oneself is indeed one of the ways of caring for others.

"I can't keep my eyes open. Maybe I'll just nip to the annex ... find a comfy spot on one of the sofas and snatch a quick nap. I can dry my clothes while I'm at it." (The Boy, 1980 P. 29 L. 1-3)

Another way to show self-respect by being respectful of others is not to be selfish and self-centered. This is demonstrated by what happened between the prisoner and Kim Jin-su when they were joined together in one cell. The fact that they suffered together made the prisoner feel that unity was enhanced, even though they didn't say anything to each other. Simply by sharing food in one plate, none of them tried to eat more than the other, considering the shortage of food.

"Kim Jin-su and I continued to receive a single tray and share its scant meal between us." (The Prisoner, 1990 P. 119 L. 18-19)

Respecting oneself and respecting others is therefore behaving with conscience, understanding what is the best thing to do for the sake of others. As it is suggested that self-respect implies an understanding of the moral meaning of being an individual, among others, who wants to live a life that has a concept of speech (Dillon, 1997), this measure of moral values is expressed in the prisoner 's perspective when he saw Kim Jin-su talking to younger protestors at the provincial office, telling them that they should be able to do so. Even if they wanted to win over the soldiers to stop the rebellion, Kim Jin-su did not want to risk the lives of others, particularly younger ones, including Dong-ho. By advising them to give up rather than fight, Kim Jin-su behaved with his conscience, advising them that searching for a way to survive is much better than sacrificing lives for the battle they knew they would not win.

"We have no choice but to surrender. If death seems the only other outcome, put down your guns and surrender right away. Look for a way to live." (The Prisoner, 1990 P. 117 L. 20-23)

Accepting responsibility for one's actions is also a way to display regard for oneself. It can be a realization that someone did the wrong thing and is sorry for it, as when Dong-ho couldn't stop accusing himself of being the one who should take the blame after Jeong-dae got shot and killed, because he came to the decision to leave Jeong-dae's body in the crowd and run away. So he was able to consider everything that Jeong-dae 's sister would do to find him.

"Isn't he your friend? Aren't you a human being? That's what Jeong-mi would scream while she thrashed you. And you would beg her forgiveness while she did." (The Boy, 1980 P. 337 L. 22-24) 
Most characters in the Human Acts blamed themselves for the loss of others. Not only Dong-ho towards Jeong-dae, but also Dong-ho's mother towards Dong-ho, Lim Seon-ju towards Dong-ho, and the prisoner towards Kim Jin-su because of their mutual pain. However, despite the guilt trip they felt, they took the burden of remaining alive as best they could to pay respect to their loved ones. To conclude the self-respect seen in the Human Acts, the characters' survival is the product of their self-esteem, which is "among the deepest human needs, so that where strong and optimistic basal self-respect does not grow and flourish, some form of self-esteem may still be rooted and strained to survive if the person is to survive" (Dillon, 1997).

\section{Respect and care for others}

In 'respect and care for others,' the third dimension of moral values, the author has nineteen findings, making it the dimension with the most findings among all. The measure of support and assistance to humanity and individuals comes with more findings than the other three indicators for this dimension.

Recognizing the bond between all people is also part of a way of showing love and caring for others as one of the aspects of the universal principles suggested by Kinnier et al. (2000). As described in the Human Acts, how the characters supported each other hand in spite of all the repercussions they could face, it is also described how they remained linked during the uprising and even years after the uprising ended. It is seen by the story of the prisoner when he encountered Kim Jin-su almost ten years after the uprising. Through his narration, he emphasized how he still felt connected even without saying anything to Kim Jin-su and vice versa, but only through a glance towards each other. It's because the rebellion left its mark on them through the misery they shared together at that time. The presence of solidarity shared between the two came from the same level of vulnerability when they fought for the same cause during the rebellion. (Prainsack, 2020).

"Your eyes would just flick down to that scrap of cotton wool then up to meet the other man's gaze, but only for a split second. That was enough to acknowledge the mark you shared. No need to linger." (The Prisoner, 1990 P. 105 L. 15-18)

Apart from the bond felt between all humans, serving and supporting humanity is also one of the ways of loving and caring for others. In Human Acts, it is not mentioned precisely how so many people were injured and killed, but it shows how hospitals and universities were full of wounded people, how people were dying from blood loss, and how unity became strength at that time by the sight of so many people lined up to support and even to give blood. Besides the blood donation, the people of Gwangju, recalled by a real life survivor, even gave him rice balls when food ran out during the rebellion (Choi, 2013). Via Dong-ho 's narration of Kim Eun-sook and Lim Seon-ju, the role of unity in the midst of misery is strongly reflected.

"Both Eun-sook and Seon-ju had gone to give blood at Jeonnam University Hospital after hearing a street broadcast saying that people were dying of blood loss." (The Boy, 1980 P. 15 L. 18-20) 
Yundayani, A., Larassaty, B. L., \& Sutrisno, B. (2021). When solidarity and misery meet in the shadow of a massacre: Moral values reflected in the novel 'Human Acts'. EduLite: Journal of English Education, Literature, and Culture, 6 (1), 105-119. http://dx.doi.org/10.30659/e.6.1.105-119

From Dong-ho's viewpoint, it is also seen how Eun-sook and Seon-ju not only supported the injured by donating their blood, but also volunteered to help take care of the victims. When Dong-ho himself was not used to the sight and smell of the bodies, Eun-sook and Seon-ju had already gotten used to it and kept doing their things, so that they could help as much as possible. Here, the presence of care and concern for others was kindly portrayed as one of the ways to be compassionate and caring for others. Knowing that the victims could not be sent home at that time, but were gathered at the provincial office where the bereaved families would come and bring them home, Eun-sook and Seon-ju gave their hands to make the bodies look decent for the families, because they did not want their families to see the horror that their loved ones had to face in their last time.

\section{"They also washed the necks and faces with a cloth, ran a comb through the matted hair to tidy it a bit, then wrapped the bodies in plastic in an effort to combat the smell." (The Boy, 1980 P. 16 L. 13-16)}

The unity between the people of Gwangju was also expressed between the soldiers and the people. This is because solidarity is versatile and expansive, representing models of social support as well as wider paradigms of social relations (Cabot, 2016). In the last chapter of the Human Acts, the writer who was searching for information on the rebellion finds new insights into some of the troops. Apparently, these soldiers could not bear the order to injure the citizens who marched together, so they tried their best to give a message instead of shooting them. This reality, found by the writer, summarizes the third dimension of moral values, which is 'respect and caring for others' through one's willingness not to injure others.

"There were soldiers who, when the order was given to fire on the crowd, pointed the barrels of their guns up into the air so they wouldn't hit anyone." (The Writer, 2013 P. 209 L. 9-11)

\section{Caring for other living things and environment}

The fourth dimension suggested by Kinnier et al. (2000), which is 'caring for other living things and the environment,' demonstrates the representation of moral principles in the Human Acts. This factor comes last with the consideration that when someone can really take care of other living creatures and the world, it means that they have taken care of themselves and other human beings first. Five results have been established through its metrics. The indicator to raise understanding of one's natural environment comes with more results than the other.

One way to demonstrate concern for other living beings and the world is by remembering one's own relation to nature. It is portrayed in the Human Acts by Eun-sook's decision to avoid consuming meat. After the uprising ended, Eunsook became editor, but her life was still lingering around the uprising to the extent that what happened there left an effect on who she is now. She could not stand seeing meat cooked because it would remind her of all the scars she took care of from the bodies of the injured and the victims. It's because Eun-sook felt the bond with the animals through the encounter she had with the people 
EduLite Journal of English Education, Literature, and Culture

Vol. 6, No. 1, February 2021, pp. 105-119

E-ISSN: 2528-4479, P-ISSN: 2477-5304

http://jurnal.unissula.ac.id/index.php/edulite

DOI: http://dx.doi.org/10.30659/e.6.1.105-119

during the Gwangju Uprising. It made her feel linked to her surroundings after it had finished.

“It wasn't so much eating meat that Eun-sook disliked; what really turned her stomach was having to watch it cook on the hot plate. When the blood and juices rose to the surface she had to look away." (The Editor, 1985 . 74 L. 10-13)

Another way to prove that one cares about other living beings and the world is by cultivating greater understanding of one's natural surroundings. As it is suggested that care and dedication to environmental altruism, especially pro-environmental behaviour, require more effort and personal sacrifice on the part of individuals (Perkins, 2010), this measure of moral values is represented from Dong-ho's mother's perspective when she was out with him years before the uprising. In her recollection, Dong-ho always asked her to walk with him under the light, so they could see the beauty of nature around them. Dong-ho's habit made him a brave boy who wasn't afraid to face something, even the horror of an insurrection, because everywhere he went, he could still see something positive in spite of the situation. When his mother went to the regional office to pick him up, Dong-ho declined to go home. He went back into the house, and his mother could only watch him as if he was walking under the light, with the unity of the people who were like the beautiful flowers that surrounded him and shielded him.

"Let's walk over there, Mum, where it's sunny, we might as well, right?... Why are we walking in the dark, let's go over there, where the flowers are blooming." (The Boy's Mother, 2010 P. 190 L. 7-11)

It is evident from all the discussions above that in the Human Acts, Han Kang tried to express the feeling she felt when she wrote it with the presence of moral values. They are seen from the inner structures of the novel and from the dimensions of the moral meaning itself. In the light of several kinds of moral values found in it, what is seen in the Human Acts, which are all aspects of the unity expressed between the characters and the people of Gwangju, is the product of the misery they experienced together during the uprising. Thus, the solidarity shared among them, in turn, has increased the resilience of their society in times of crisis (Prainsack, 2020).

\section{CONCLUSION}

Based on the results and discussions in which the author discussed the conclusions of this literary study, the moral principles set out in the novel Human Acts by Han Kang are related to the pain and unity shared by the characters in the novel. Despite most of the moral values present in some chapters, the dispersion of all aspects of moral values is in line with the intrinsic frameworks of the novel itself. This implies that the message that Han Kang wants to share with readers through pain and unity shared among the people of Gwangju during one of the most difficult times they've ever encountered has been reasonably delivered. The manner in which Han Kang portrayed everything in the Human Acts, based on her own study and documentation prior to and 
Yundayani, A., Larassaty, B. L., \& Sutrisno, B. (2021). When solidarity and misery meet in the shadow of a massacre: Moral values reflected in the novel 'Human Acts'. EduLite: Journal of English Education, Literature, and Culture, 6 (1), 105-119. http://dx.doi.org/10.30659/e.6.1.105-119

during the writing of the novel, showed that unity and misery were not mere myth, but that they were realistically seen at that time.

While moral values exist and are seen in everyday life with or without the need to be emphasized, under some conditions, such as an insurrection, they become much more important and visible. It's because, in that case, people come to understand how the pain they share will lead them to their survival through the unity they build up along the way. Solidarity, developed in the midst of misery, is known to be one of the truest definitions of moral principles, appropriately reflected in the Human Acts.

\section{REFERENCES}

Alexander, J. C. (2016). Culture trauma, morality and solidarity: The social construction of 'Holocaust' and other mass murders. Thesis Eleven, 132(1), 3-16. https: / / www.ceeol.com/search/article-detail?id=836476.

Ariyanti, A. (2016). Moral Values Reflected in "The House on Mango Street" Novel Written by Sandra Cineros. EFL Journal, 1(1), 25. https://doi.org/10.21462/eflj.v1i1.2.

Cabot, H. (2016). "Contagious" solidarity: Reconfiguring care and citizenship in Greece's social clinics. Social Anthropology, 24(2), 152-166. https://doi.org/10.1111/1469-8676.12297.

Choi, S. (2013). Protesting identity: Memories of the Kwangju uprising and effects on identity formation of youths. Educational Perspectives, 46(1\&2), 9-19. https://eric.ed.gov/?id=EJ1088346.

Creswell, J. W. (2012). Educational research: Planning, conducting, and evaluating quantitative and qualitative research (4th Ed.). Pearson.

Dillon, R. S. (1997). Self-Respect: Moral, Emotional, Political. Ethics, 29, 226-249. https://www.journals.uchicago.edu/doi/pdf/10.1086/233719.

Djamba, Y. K., \& Neuman, W. L. (2002). Social Research Methods: Qualitative and Quantitative Approaches. In Teaching Sociology (Vol. 30, Issue 3). https://doi.org/10.2307/3211488.

Fraenkel, Jack R., \& Wallen, Norman E. (1993). How to design and evaluate research in education. Second edition. McGraw-Hill Inc.

Harahap, A. M., \& Utami, S. (2019). The representation of gwangju uprising in Human Acts Novel. English and Literature Journal, 6(2), 186-198. https://doi.org/10.24252/elite.v6i2a6.

Hartanto, E. (2018). Reading Han Kang's Human Acts: The process of remembering and forgetting the memory of the past South Korea. Proceedings of the The 1st International Conference on Education, Language, and Literature (Icon-Elite) (pp. 265-270). Surabaya, Indonesia.

Kahn-Chae, N. (2003). Collective action and organization in the Gwangju uprising. New Political Science, 25(2), 177-192. https://doi.org/10.1080/07393140307196

Kang, H. (2016). Human acts. Hogarth

Kaur, S. (2015). Moral values in education. Guru Gobind Singh Khalsa College for Women, Jhar Sahib. IOSR Journal of Humanities and Social Science (IOSR-JHSS) 20(3), Ver. III, 21-26. 
EduLite Journal of English Education, Literature, and Culture

Vol. 6, No. 1, February 2021, pp. 105-119

E-ISSN: 2528-4479, P-ISSN: 2477-5304

http://jurnal.unissula.ac.id/index.php/edulite DOI: http://dx.doi.org/10.30659/e.6.1.105-119

Kinnier, R. T., Kernes, J. L., \& Dautheribes, T. M. (2000). A Short List of Universal Moral Values. Counselling and Values, 45(1), 4-16. https://doi.org/10.1002/j.2161007x.2000.tb00178.x.

Klarer, M. (2016). An Introduction to Literary Studies. Second edition. Routledge

Laitinen, A., \& Pessi, A. B. (2005). An introduction to theory and practice. Solidarity: Theory and practice. An Introduction, 44.

Lickona, T. (1996). Eleven Principles of Effective Character Education. Journal of Moral Education, 25(1), 93-100. https://doi.org/10.1080/0305724960250110.

Marsh, Nicholas. (2002). How to begin studying English literature. Third ed. Palgrave

Mayerfeld, J. (1999). Suffering and moral responsibility. Oxford University Press.

Perkins, H. E. (2010). Measuring love and care for nature. Journal of Environmental Psychology, 30(4), 455-463. https://doi.org/10.1016/j.jenvp.2010.05.004.

Prainsack, B. (2020). Solidarity in Times of Pandemics. Democratic Theory, 7(2), 124133. https://doi.org/10.3167/dt.2020.070215.

Rakopoulos, T. (2016). Solidarity: The egalitarian tensions of a bridge-concept. Social Anthropology, 24(2), 142-151.

Wellek, R., \& Warren, A. (2012). Theory of literature. Harcourt, Brace and Company.

Zyngier, S. (1994). Introducing literary awareness. Language Awareness, 3(2), 95-108. https://doi.org/10.1080/09658416.1994.9959846.

Conflict of Interest Statement: The authors declare that the research was conducted in the absence of any commercial or financial relationships that could be construed as a potential conflict of interest.

Copyright (C) 2021 Yundayani, Larassaty, and Sutrisno. This is an open-access article distributed under the terms of the Creative Commons Attribution License (CC BY). The use, distribution or reproduction in other forums is permitted, provided the original author(s) and the copyright owner(s) are credited and that the original publication in this journal is cited, in accordance with accepted academic practice. No use, distribution or reproduction is permitted which does not comply with these terms. 